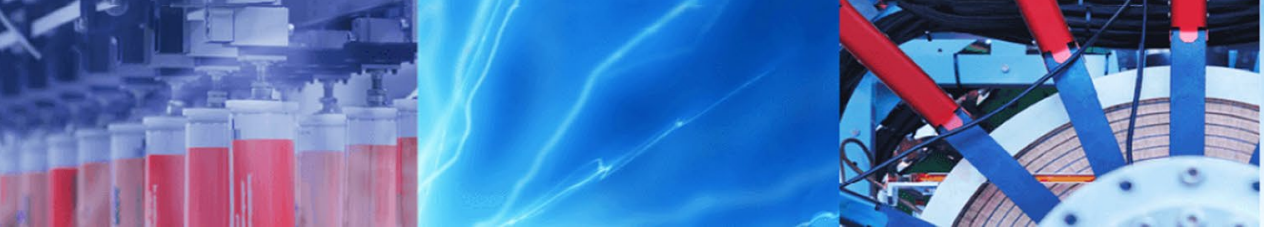

Research Article

\title{
Investigating impact of land-use and land cover changes on hydro-ecological balance using GIS: insights from IIT Bombay, India
}

\author{
Aman Srivastava ${ }^{1}$ (D) Pennan Chinnasamy ${ }^{1,2} \mathbb{D}$
}

Received: 11 October 2020 / Accepted: 2 February 2021 / Published online: 17 February 2021

(C) The Author(s) 2021 OPEN

\begin{abstract}
The present study, for the first time, examined land-use land cover (LULC), changes using GIS, between 2000 and 2018 for the IIT Bombay campus, India. Objective was to evaluate hydro-ecological balance inside campus by determining spatio-temporal disparity between hydrological parameters (rainfall-runoff processes), ecological components (forest, vegetation, lake, barren land), and anthropogenic stressors (urbanization and encroachments). High-resolution satellite imageries were generated for the campus using Google Earth Pro, by manual supervised classification method. Rainfall patterns were studied using secondary data sources, and surface runoff was estimated using SCS-CN method. Additionally, reconnaissance surveys, ground-truthing, and qualitative investigations were conducted to validate LULC changes and hydro-ecological stability. LULC of 2018 showed forest, having an area cover of 52\%, as the most dominating land use followed by built-up (43\%). Results indicated that the area under built-up increased by $40 \%$ and playground by $7 \%$. Despite rapid construction activities, forest cover and Powai lake remained unaffected. This anomaly was attributed to the drastically declining barren land area (up to 98\%) encompassing additional construction activities. Sustainability of the campus was demonstrated with appropriate measures undertaken to mitigate negative consequences of unwarranted floods owing to the rise of $6 \%$ in the forest cover and a decline of $21 \%$ in water hyacinth cover over Powai lake. Due to this, surface runoff ( $~ 61 \%$ of the rainfall) was observed approximately consistent and being managed appropriately despite major alterations in the LULC. Study concluded that systematic campus design with effective implementation of green initiatives can maintain a hydro-ecological balance without distressing the environmental services.
\end{abstract}

Keywords Land-use land cover · Rainfall-runoff · Sustainable development · Remote sensing · GIS · Hydrology

\section{Introduction}

India represents the third-largest higher education system in the world next to China and the USA [60]. There are in total 35,539 affiliated public and private colleges and 700 degree-granting universities in India. Being a developing country, educational institutions are constantly evolving and expanding across the states. Infrastructural development in terms of physical (constructions), social (communication network), and economic (finance and banking) aspects is highly influenced by development and economy $[8,14,67]$. Infrastructure development in colleges and universities is becoming an essential element of a learning environment. Therefore, it becomes vital to understand the degree of construction for establishing academic infrastructure which has been known to significantly impact the environmental and ecological balance as a whole [59]. The rapidly urbanizing colleges or universities (in terms of physical infrastructure) have been mainly attributed to the construction activities. This includes the construction

\footnotetext{
$\triangle$ Aman Srivastava, amansrivastava1397@gmail.com; Pennan Chinnasamy, p.chinnasamy@iitb.ac.in | ${ }^{1}$ Centre for Technology Alternatives for Rural Areas (CTARA), Indian Institute of Technology Bombay, Mumbai 400076, India. ${ }^{2}$ Rural Data Research and Analysis (RuDRA) Lab, Indian Institute of Technology Bombay, Mumbai 400076, India.
} 
of academic buildings, classrooms, laboratories, assembly halls, libraries, playgrounds, roads, parking areas, etc. [70]. Apart from this, the construction of water bodies in the form of a small reservoir, such as Powai lake on the campus of the Indian Institute of Technology Bombay, located in Mumbai, India, also presents an example of construction activities contributing to the campus infrastructure development. The increase in the construction activity within the boundary of the academic institution or as such any town or catchment will change the hydrology, especially the rainfall-runoff behavior and the land-use land cover (LULC) pattern [50]. Such changes may have a negative impact on the environment if there is a lack of a proper LULC development plan and suitable measures for sustainable development of the institutions [63]. The rainfall-runoff process is known to be related to complex factors, such as changes to river network morphology, construction of drainage system, water transfer, and changes in LULC $[48,72]$. Most infrastructure development requires establishing new buildings, for which land has to be cleared, deforested, and leveled for the basement. In such conditions, the increased concrete cover and road network, due to infrastructural development, prevents infiltration of the rainwater resulting in flashier surface runoff and less natural infiltration [32]. The increased concrete cover also impacts groundwater-surface water interaction and as such impedes the natural hydrological cycle. This results in decreased time to peak in the hydrograph and increased peak discharge and volume, causing increased surface runoff and decreased groundwater infiltration. Such situations subsequently lead to a higher risk of flooding within the campus of the educational institution or the neighboring regions [75].

The information on LULC in the form of statistical data and maps is an essential requirement for better utilization of land, spatial planning, and management $[2,10,12,64]$. With the increasing demand for the availability of information on LULC, it becomes equally important to have a uniform procedure of mapping and data collection, a detailed definition of LULC, and its categories on different scales [3]. On this note, studies using remote sensing (RS) techniques and Geographical Information System (GIS) have largely focused on providing the technical knowledge on the process and the type of LULC changes and rainfall-runoff process [33]. With the growth of satellite technology, many satellite imageries are processed and available for the general public as open-source products. RS-derived LULC maps, can provide vital information to help managers best understand the current landscape and propose changes. LULC maps can also aid in understanding the change over time by analyzing LULC maps over several different years. With this information, land managers can evaluate past management decisions and land-use patterns as well as gain insight into the possible effects of their current decisions before they are implemented [44, 56]. On the other hand, GIS software offers a unique set of capabilities for applying location-based analytics to hydrological process practices. It produces the results via maps, apps, and reports $[3,16,33,36,47,58]$.

Open-source digital platforms, such as Google Earth Pro, is commonly used for analyzing Earth observation data on land transformations. Google Earth Pro, released in 2004 (initially named as Earth Viewer 3D) by Keyhole Inc., a Central Intelligence Agency (CIA) funded company acquired by Google, is a Graphical User Interface (GUI) tool. Based on satellite imagery, it provides a three-dimensional model of the Earth and two-dimensional geographical information via maps. The key feature of Google Earth Pro is that it provides a free high-resolution imagery database from different satellite platforms, such as CNES Airbus, Landsat, and Copernicus [73]. Google Earth Pro includes many tools that help visualize a location at different spatial and temporal scales, measure distances, create polygons and areas of interest (Aol), add locations via latitude and longitude information, and export data in various formats (for more information: https://www.google.com/earth/ versions/).

Several previous studies have extensively used Google Earth Pro for investigating and analyzing natural resources, hydrological balance, ecological stability, LULC changes, navigation, agricultural watersheds, geosciences, and archeological findings from across the globe $[11,13,34$, $37,68,71$. Afrin et al. [1] developed LULC maps for the year 2016 using Landsat-8 and MODIS data for hydroecological applications on the Athabasca river watershed. Their results served as important decision support tools for policy-makers and local regulatory authorities of the Athabasca river. In another study on evaluation of the hydro-ecological stability of the Punarbhaba river, Pal and Talukdar [49] demonstrated alteration due to the installation of Komardanga dam causing expansion in agricultural land cover and decline in water body cover by developing LULC maps for pre- (1989) and post-dam (2015) phases. Zekeng et al. [74] showcased the impacts of agroforestry and deforestation on Doume Communal Forest in Eastern Cameroon by developing LULC maps using Landsat images for the period 2000-2018. In all the aforementioned studies, authors used automated or semiautomated classification techniques, such as supervised classification for defining land-use classes. These methods require an accuracy assessment to ensure the reliability of the generated final land-use classes.

Generating LULC classes using a manual supervised classification technique is yet another approach adopted in land transformation studies [11, 65]. Yu and Gong [73] and Liang et al. [39], in a review on the applications of 
Google Earth Pro, indicate that there has been a profound impact of Google Earth versions on scientific research, academic, and industrial communities. Most of these studies used a manual classification method, wherein, as per Taylor and Lovell [69], imagery from the Google Earth Pro database was manually ground-truthed by zooming into pixels to differentiate between natural settings and constructed settings. For example, Chaware et al. [9] used the aforementioned approach to develop a simple and replicable approach for combating inadequate groundwater data issues by considering biophysical and environmental factors. Their studies concluded that Google Earth Pro has immense potential for global application, especially for the cases, wherein historical data, such as groundwater variability, are inadequate and thus can assist in achieving better management and governance. Chinnasamy and Parikh [11] used the manual classification technique to estimate the violations in coastal regulation zones along the Maharashtra coastline and showcased the potential of Google Earth Pro for larger study area applications. In general, despite advances in automated and semi-automated classification techniques, Castilla et al. [7] and Goldblatt et al. [17], in their reviews, argue that the manual photointerpretation remained the preferred method of choice for producing fine-scale LULC maps. In fact, Taylor and Lovell [69] indicate that manual photointerpretation and landuse classification has advantages over automatic classification, as real objects are better captured in manual methods, especially for fine-scale studies. In addition, interpreting the satellite imagery using Google Earth Pro provides historical analysis in terms of variations in the season, the extent of vegetation, as well as differentiating the real-world using tone, color, pattern, and their correlation with the neighboring object that cannot be attained in automated extraction $[35,40]$. Hence, the present study employed Google Earth Pro for developing LULC maps using a manual supervised classification technique.

The number of universities is increasing and expanding in terms of land area to accommodate the increasing number of students by constructing a greater number of hostels in an academic institution. Therefore, understanding and quantifying the spatio-temporal dynamics of the institution's LULC changes and its driving factors are crucial to put forward the right policies and monitoring mechanisms for planners and policymakers [44]. Also, it becomes vital to understand the sustainability of the infrastructural development of these institutions on the surrounding physical environment, such as trees, vegetation, water bodies, and other land uses along with hydrological and meteorological parameters, for example, rainfall, surface runoff, groundwater recharge, rate of evaporation, temperature, and humidity. Under these contexts, there is a need to develop an understanding of infrastructural development planning initiatives through a sustainability lens, given changing LULC patterns and their impacts on rainfall-runoff behavior [38]. Hence, the present research, for the first time, aimed to study the case of one of the premier engineering institutes of India-the Indian Institute of Technology Bombay (IITB)—Mumbai, situated in the Maharashtra state of West-India [26]. The institute has grown in size and scale as well as in the range of activities it undertakes since its establishment in 1958 [26]. The recent rapid expansion in student numbers in the campus has put the demand for more construction of the hostels. At the same time, various initiatives have been taken for the past couple of decades regarding the further construction of the departments and centers on the campus. As per the information from the official website of IITB, it is claimed that there has been increasing cover of vegetation and forest simultaneously with infrastructural development $[20,21,26]$. To some extent, the impacts of the Mumbai floods are also experienced by the campus of IITB (Achary and Yughabala, personal communication, March 9, 2020). Therefore, the study of the rainfall-runoff behavior, given rapid infrastructural development, becomes important so as to understand the resilience of the campus towards flood events in particular and hydro-ecological and environmental balance in general.

\subsection{Study objectives}

Dunbar and Acreman [15] have broadly defined hydroecology as the linkage of knowledge from hydrological, hydraulic, geomorphological, and ecological sciences to predict the response of ecosystems to variation of abiotic factors over a range of spatial and temporal scales. In the context of the present study, the hydro-ecological balance has considered three broad facets, viz., the spatiotemporal disparity between hydrological components (rainfall-runoff process), ecological components (forest, vegetation, lake, and barren land), and anthropogenic stressors (urbanization). The broad intent of the study is to focus on quantifying their impacts on the green components of IITB campus. The primary objectives are, first, to examine the change in the LULC pattern of the campus from the period of 2000 to 2018 using RS and GIS; second, to identify the relation between the increasing built-up cover and its implications on the rainfallrunoff behavior; and third, to explicitly understand the significance of the rapidly changing land-use behavior on the hydro-ecological balance of the campus at large. The secondary objectives of this study are first to understand how the infrastructural development in IITB has changed the LULC pattern and potential impacts, if any, on the green cover in terms of forest and vegetation; and second, to propose recommendations and approaches 
for sustainable campus development initiatives intending to increase green cover amidst new infrastructure development.

The aforementioned objectives require good quality and quantity of observation data. For example, good quality and quantity of rainfall data were acquired from the Regional Meteorological Center (RMC), located in Mumbai for the present study site; however, obtaining such data for other parameters, such as vegetation, forest cover, was challenging. In such instances, when observation data are limited, the use of RS data and GIS has been widely used to address data gaps. This paper presents an integrated study using secondary data, RS, GIS, and field observations for the IITB campus.

\section{Methods}

\subsection{Study site}

The IITB campus is located in the financial and commercial capital of India-Mumbai, between the Powai lake and Vihar lake region, at a geographical location between $19^{\circ} 8^{\prime} 01.09^{\prime \prime} \mathrm{N}$ and $72^{\circ} 54^{\prime} 55.29^{\prime \prime} \mathrm{E}$ (Fig. 1). The IITB campus shares its border with the Sanjay Gandhi National Park, which has significantly influenced the green cover of the campus and aids in reducing air pollution inside the campus [26]. Since its establishment (in the year 1958), the institute has physically expanded to a combined area of approximately 550 acres $\left(2.23 \mathrm{~km}^{2}\right)$ with 584 major buildings. Although the official campus area allocated to IITB was 550 acres in 1958, but across the 50-year timeline, the area utilized was only 420 acres [42]. Currently, IITB's academic buildings comprise 14 departments, 31 centers, five interdisciplinary centers, two schools, and one hospital [27]. Moreover, the institute is rich in natural flora and fauna with more than 80 plant species and over 95 bird species along with an increasing number of trees [31]. The adjacently located Powai lake, having an area of $2.34 \mathrm{~km}^{2}$ (as recorded from satellite imagery), has been known to enrich the biodiversity within the campus $[27,31]$.

\subsection{Data collection and data processing}

The data acquisition of the present research was based both on quantitative (secondary data-based) and qualitative (survey-based) research methods aiming to investigate LULC changes in the campus of IITB between 2000 and 2018. An open-source GIS platform-QGIS and satellite data from Google Earth Pro-was employed for developing LULC maps. Besides this, rainfall data and curve number data were also collected from secondary sources

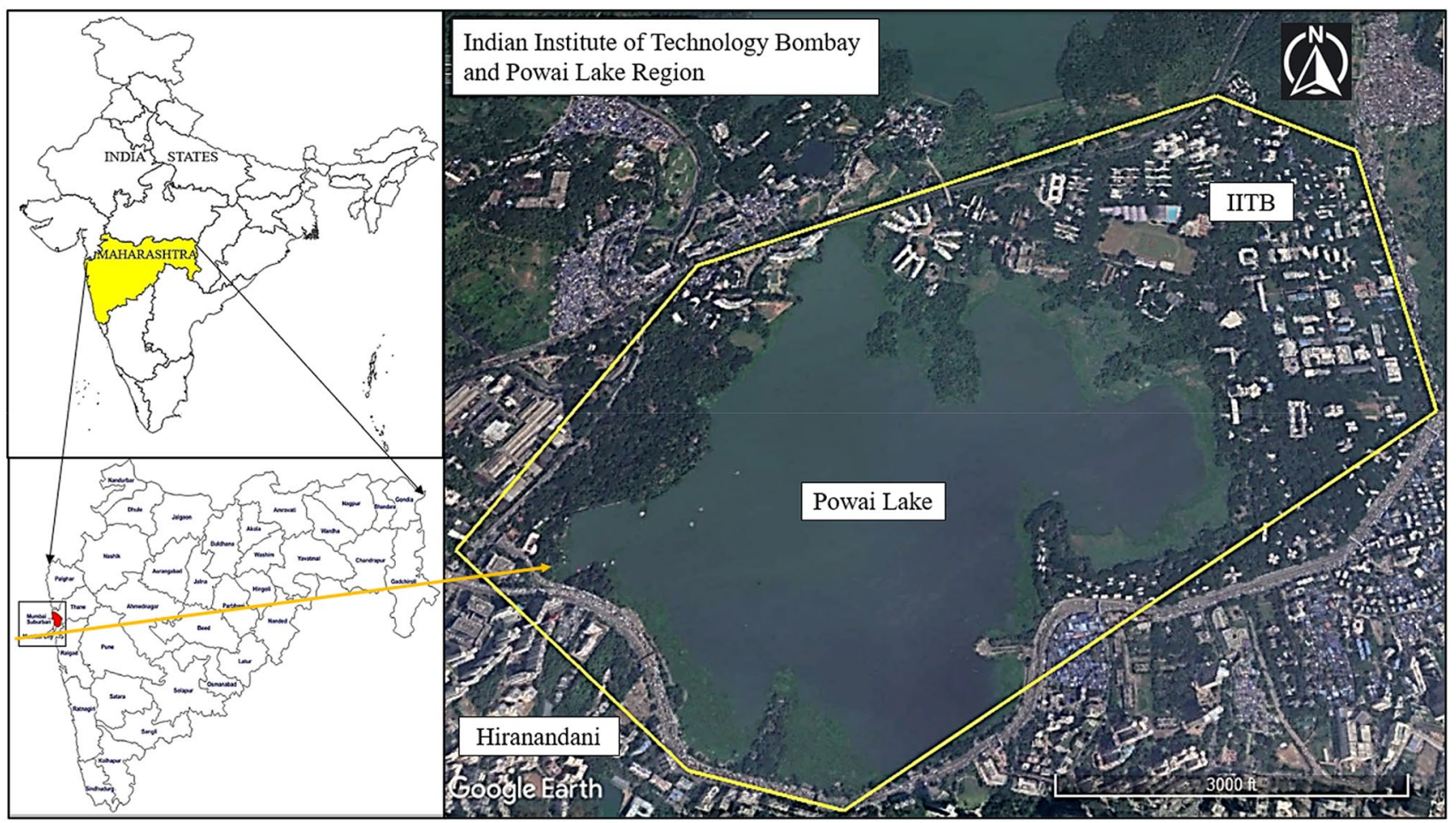

Fig. 1 Location of the study site, Indian Institute of Technology Bombay (IITB) (insets showing the location in Maharashtra state and India) 
for estimating surface runoff and further analysis of the rainfall-runoff process.

\subsubsection{Rainfall (P)}

The rainfall data $(P)$, from 2000 to 2018, for the Santacruz region of Mumbai were collected from the RMC, Mumbai region [55]. Santacruz region is located at an average distance of $9 \mathrm{~km}$ from the IITB campus and houses the closest rain gauge station to the Powai region. The rainfall data for the years 2000, 2003, 2009, 2011, 2012, 2014, 2015 , and 2018 were used for the calculation of runoff. The same rainfall years were compared with the average annual rainfall of Mumbai to estimate the annual rainfall departure. Also, with the availability of the LULC data, the rainfall data were used to estimate the $W C N$ and runoff volume $(R)$ for each study year.

\subsubsection{Remote sensing (RS) using Google Earth Pro}

Considering the advantages of the manual classification of the high-resolution satellite imagery for a fine-scale study area, Google Earth Pro is used. The RS data were collected by developing a boundary map of the IITB campus by digitizing it in Google Earth Pro (as shown in insets of Fig. 1). The study period 2000-2018 was selected, as a clear Google Earth image before 2000 was unavailable. Within this boundary, the polygon tool was used for landuse classifications using the manual supervised classification method to qualitatively and quantitatively estimate the changes in the LULC. The land-use classes identified inside IITB campus included Powai lake (without considering water hyacinth cover), water hyacinth (WH) cover, forest cover (including vegetation), built-up (infrastructure inclusive of residential buildings, administrative/ educational buildings, hostels, roads, swimming pool), playground (open field), and barren land (the part of the land not included in above land covers).

Due to the undulating topography of the study area, ground reference data were collected from Google Earth Pro with Ground Control Points (GCPs). As the total study area was small $\left(\sim 4.6 \mathrm{~km}^{2}\right)$, each LULC type was groundtruthed using the reconnaissance survey for accuracy assessment. The GCPs for thematic accuracy were collected near the boundary between different LULC classes, whereas GCPs for position accuracy were taken on easily recognizable elements in the satellite images, such as playground corners, building (built-up) edges, bank of Powai lake, and nursey corners. The OSMTracker (online Global Positioning System App) was used to validate the geographical locations. The accuracies of classification were observed better than expected. A negligible error was recorded in the overall accuracy of the classification image for the year 2018, wherein an overall accuracy ranging between 90 and $96 \%$ was obtained. Finally, based on these land-use classifications, a Google Earth KML file was obtained for each LULC type.

\subsubsection{QGIS processing}

The KML files, obtained from Google Earth Pro, were postprocessed in QGIS to estimate the area. The steps included, (1) exporting the KML file to QGIS; (2) converting the KML file into shapefile; (3) generating a LULC image of the IITB campus by defining its boundary (legends) and by assigning different colors for different land uses. Six major LULC classifications were found in the ground survey, which was used for the RS imagery. Following these, LULC maps were generated for the years 2000, 2003, 2009, 2011, 2012, 2014, 2015 , and 2018. The selections of these years were based on the availability of cloud-free satellite imagery. Then, the change in LULC was analyzed to depict gains and losses of different land-use classes for the period 2000-2018. The percentage gains and losses for each land-use were derived by comparing their area cover in 2018 with 2000.

\subsubsection{Soil conservation services-curve number (SCS-CN)}

The SCS-CN method, as developed by the US Department of Agriculture (USDA) Soil Conservation Service (SCS), primarily aimed at estimating rainfall excesses from rainfall [18]. The method has been readily accepted and used widely in numerous hydrologic studies to estimate surface runoff, such as for ungauged agricultural watersheds, quantifying vulnerability of soil erosion, and the studies monitoring spatio-temporal variability in LULC patterns $[41,43,52-54]$. The SCS-CN method for the Indian conditions was used in the estimation of surface runoff from the IITB campus. In the determination of $C N$, the hydrological soil classification group-C (moderately high runoff potential) and Antecedent Moisture Condition type-II (AMC-II) were adopted based on the site conditions and as per Zope et al. [75], Boughton [6], and Subramanya [66]. The curve number for AMC-II (represented as $\left(N_{\| l}\right.$ ) was identified for the six LULC classifications. The Powai lake (including WH cover), built-up, barren land, playground, and forest cover were assigned with $C N$ equal to 100,85 , 79,69 , and 64 , respectively. The weighted $C N$ was obtained after multiplying the specific $C N$ of a particular year with its corresponding land-use area $(A)$. This was essential for the comprehensive estimation of the surface runoff from the various land uses from the IITB campus in a given study year. 


\subsection{Runoff $(R)$ and weighted curve number (WCN) estimations}

Using the rainfall $(P)$, area of each land cover type $(A)$, and runoff curve number $(C N)$ estimations, as described in Sects. 2.2, the runoff volume $(R)$ was calculated as the product of $P, A$, and, $C N$. The WCN was calculated to determine the overall impact of different land uses over rainfallrunoff behavior inside the campus. For this, the total runoff volume $\left(R_{1, t}+R_{2, t}+R_{3, t}+R_{4, t}\right)$ from the major four land-use classifications viz., (1) built-up, (2) forest, (3) playground, and (4) barren land were considered, as they were primarily resulting into surface runoff. The $R$ was calculated for each year $(t)$ and divided with the corresponding annual rainfall $\left(P_{t}\right)$ received in that particular year $(t)$. With this, the value of $W C N$ for all the mentioned years in the given study period was obtained.

\subsection{Qualitative and field investigations}

The primary data were used in this study for understanding the nuances of the secondary data, given the behavior of rainfall-runoff components and associated measures being taken to manage the campus development initiatives. The purpose of bringing qualitative investigations in this study was to acquire field insights and understanding people's perception of the changing rainfall-runoff behavior. Key qualitative findings were included in the present study based on personal communication with the residents of the IITB campus (Achary and Yughabala, personal communication, March 9, 2020).

Field investigations were conducted inside the campus, which included transect walks at the periphery of the Powai lake and reconnaissance survey, thereby creating social and resource maps indicating diverse land uses. The investigation primarily ground-truthed two facets viz., (1) ascertaining the socio-economic patterns impacting and regulating provisions for groundwater percolation (from green cover) and surface runoff (from built-up cover) and (2) understanding the distinctions of green cover in terms of vegetation, forest cover, and barren land with infrastructural development.

\section{Results}

\subsection{Rainfall-runoff analysis}

The average annual rainfall in the study period was recorded to be $2,331 \mathrm{~mm}$, with a maximum rainfall observed in the year $2011(3,129 \mathrm{~mm})$ and the least rainfall received in the year $2015(1,800 \mathrm{~mm})$ (Fig. 2), whereas the annual average rainfall of Mumbai was $2,168 \mathrm{~mm}$ with
July as the wettest month $(682 \mathrm{~mm})$ and January, February, and March as the driest months in a year [45]. In general, the percentage surpluses in the rainfall received in the IITB region were $7.5 \%$ more than the average annual rainfall of Mumbai. Comparatively higher rainfall in the IITB region was attributed to its geographical location, its proximity to Sanjay Gandhi National Park, and the existence of dense forest cover within the campus boundary. The SCS-CN approach indicated that the average runoff in a year from the catchment of the campus (across all land-use classifications) was directly correlated to the magnitude of rainfall received in the same year (Fig. 2). On average, about 61\% of the rainfall was observed flowing as surface runoff from the campus between 2000 and 2018. Maximum runoff was recorded in the year 2018 (63\%), while 2012 recorded the least runoff (60\%) from the campus area. Most of this runoff, after atmospheric and groundwater losses, was routed to the Powai lake, via canals in IITB. Subtracting these losses from the rainfall and runoff would lead to the storage volume of Powai lake. However, estimating volume of the lake is the future scope of the present study.

\subsection{Qualitative analysis on LULC changes}

The LULC maps for the years 2000, 2003, 2009, 2011, 2012, 2014, 2015, and 2018 were analyzed using satellite imagery (Fig. 3). Comparative qualitative analysis of the LULC maps of 2000 and 2003 provided two inferences, viz., first, the built-up area increased from 2000 to 2003. It was during this time the construction of the 12th hostel (having the capacity to accommodate $>500$ students) was completed. Second, the WH cover of Powai lake was found significant from all sides of the lake. The Powai lake at Hiranandani (located at the opposite side of Powai lake; refer to Fig. 1) was observed with a comparatively greater WH cover between 2000 and 2003 concerning the IITB side, while comparative analysis of the LULC maps of 2009 and 2011 indicated a significant increase in the builtup area due to the construction activities of new departments and hostels (such as the hostels 13 and 14 hostel having the capacity to accommodate $>500$ students each). On the flip side, a rapid decline in the barren land cover was observed as a result of establishing new infrastructures. Between 2003 and 2011, the overall WH cover was observed diminishing. Remarkably, the WH cover significantly improved (area reduced) at the Hiranandani side; however, its cover remained prevalent at the IITB side. The LULC pattern since 2011 indicated an increasing trend for built-up cover and a decreasing trend for WH cover, especially at the Hiranandani side. Also, during the same period, several projects on further construction of the hostels to accommodate a rising number of students marked the initiation for the hostels $15,16,17$, and 18 hostel (each 


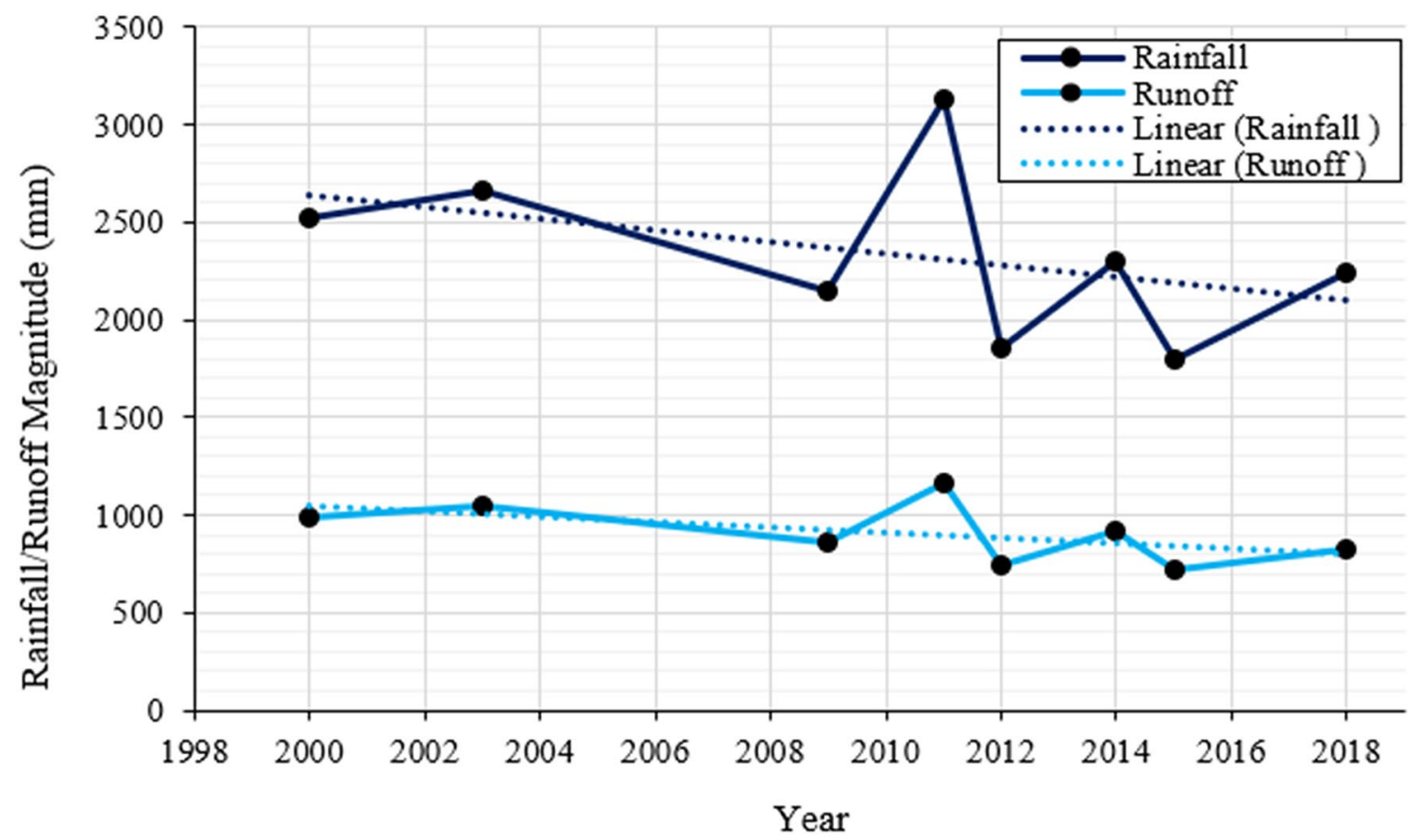

Fig. 2 Variation in annual average surface runoff generated against the annual average rainfall between 2000 and 2018 from the campus of Indian Institute of Technology Bombay (IITB), India

having the capacity to accommodate $>500$ students). This consistently kept reducing the barren land cover as observed in the imagery analysis (Fig. 3).

\subsection{Quantitative analysis of LULC trends}

The changes in LULC for playground, built-up, forest, and barren land between 2000 and 2018 are summarized in Fig. 4. The biggest land cover area belonged to the dense forest of the IITB campus throughout the study period followed by built-up cover. The area under barren land was the third major land-use until 2015, post which, its area cover depleted below the area under the playground. Overall, an increasing trend was observed for the areas under the playground and built-up cover, while in the case of forest cover, the increment was rather fluctuating across the study period. The barren land cover was the only land-use showing a decreasing trend. Among these four LULCs, the percentage contributed by forest cover in the year 2000 was $51 \%$, while that of the built-up was $32 \%$. On the other hand, the barren land and playground contributed $14 \%$ and $3 \%$, respectively (sum of all these four LULC gives $100 \%$; exclusive of Powai lake). However, by comparing the percentage cover of the LULC of 2000 with 2018, it was identified that the forest cover contribution in 2018 became $52 \%$, while the built-up cover recorded $43 \%$ area. Though the sum percentage cover of forest and playground (4\%) was observed nominal, the increment in the percentage built-up cover contribution was rather significant (11\%) across these 18 years. Despite the rapid increase in the built-up area, the forest cover remained more or less unaffected. This was attributable to the percentage decline recorded in barren land from $14 \%$ contribution in the year 2000 to nearly $1 \%$ contribution in the year 2018 (Fig. 4).

\subsection{Water hyacinth cover and its impact over the Powai lake}

The analysis of Powai lake, having an area of about 2.34 $\mathrm{km}^{2}$, was based on the visible area under satellite imagery for water cover (lake) and the WH cover between 2000 and 2018 (Fig. 5). The study identified that the percentage cover of WH in 2000 was $38 \%$ of the total area of the lake, which subsequently increased to $42 \%$ in 2003 . Since then, the WH cover showed a decreasing trend and thus observed a further decline to $17 \%$ in 2018 . As evident from Fig. 6, the total area of the lake cover in the year 2018 was identified to be $1.94 \mathrm{~km}^{2}$, while the average area of the lake between the years 2000 and 2003 was about 1.38 $\mathrm{km}^{2}$. Overall WH cover was observed decreasing, but the spatial interpretation from the imagery points toward an unequal decrease at both sides of Powai lake (Hiranandani and IITB). Continuing the argument made for this anomaly in Sect. 3.3, two reasons were identified behind this 

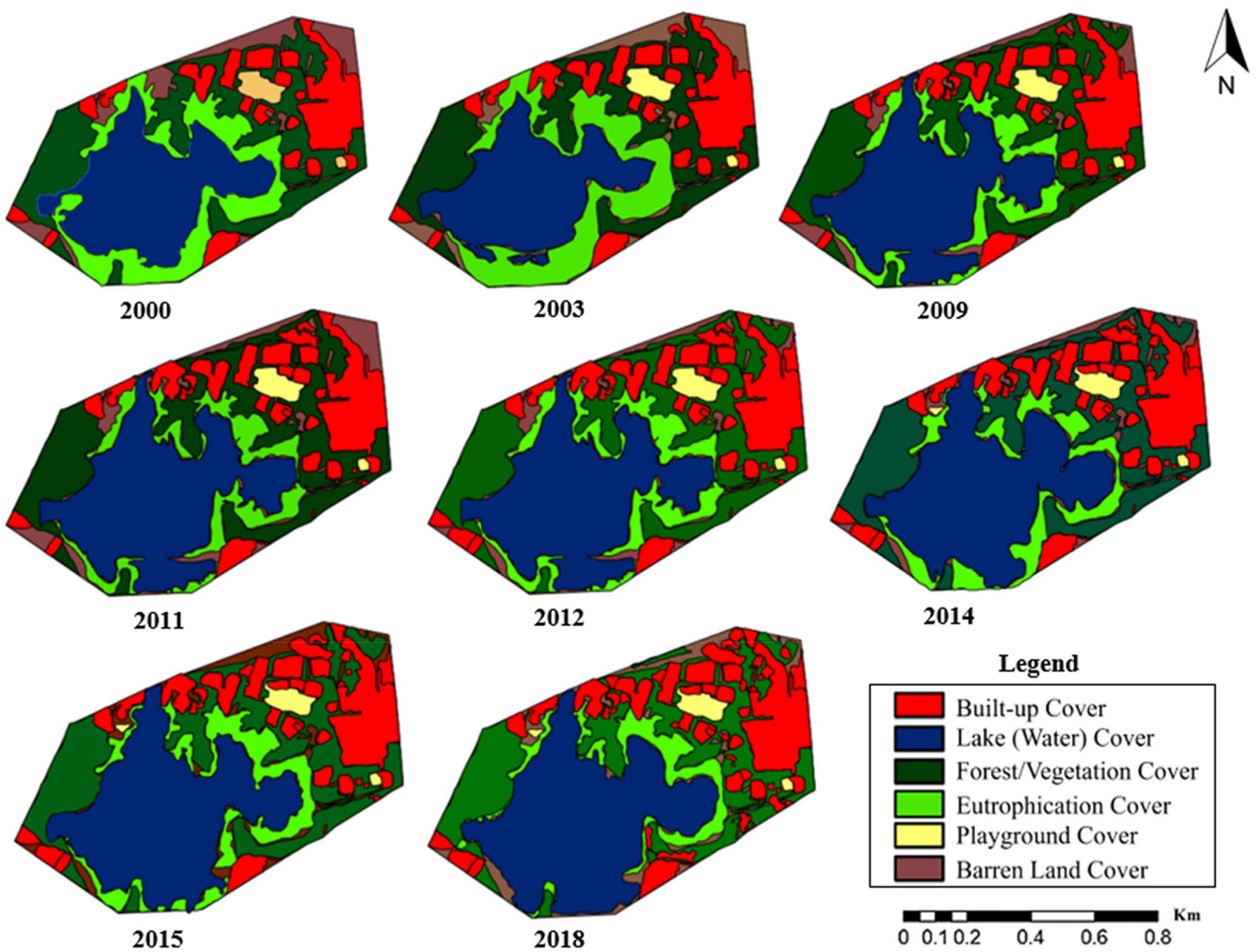

Fig. 3 Spatial and temporal analysis of land-use land cover (LULC) change between 2000 and 2018 in the campus of the Indian Institute of Technology Bombay (IITB), India

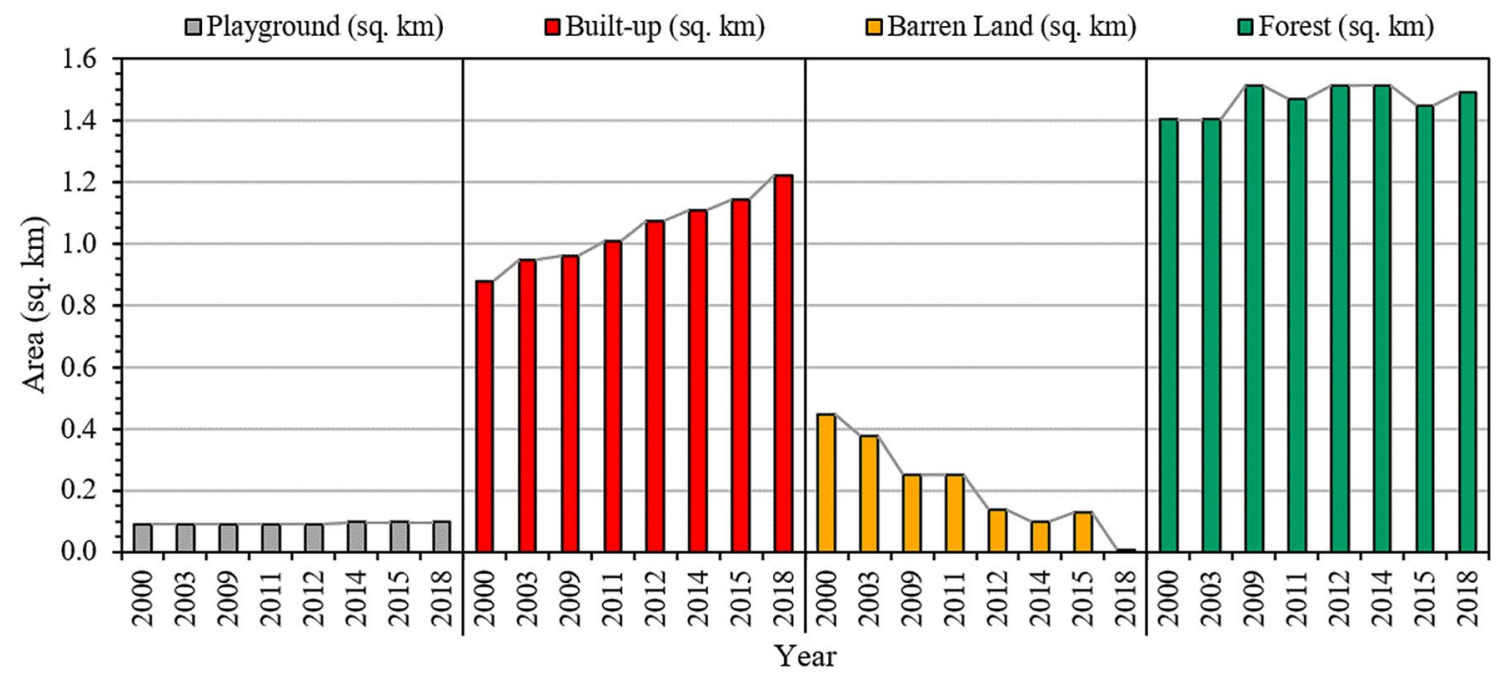

Fig. 4 Temporal analysis of change in land-use land cover (LULC) between 2000 and 2018 for the campus of the Indian Institute of Technology Bombay (IITB), India 
unequal decrease in the WH cover of Powai lake (Achary and Yughabala, personal communication, March 9, 2020). First reason: the Hiranandani region was recognized for both a residential complex having skyscrapers as well as a tourist place. In order to maintain its tourism, the Powai lake in this zone was being maintained that substantially reduced the WH cover. As a result, significant revival and restoration of the lake, at least on the Hiranandani side, were attained. Second reason: the management of the Powai lake, in general, was carried out by three different agencies, IITB administration and associated organizations within the institute; the private maintenance team of Hiranandani complex and associated Non-Government Organizations (NGOs) of the Powai region, and the Brihanmumbai Municipal Corporation (BMC) along with the Public Works Department (PWD) of Mumbai. Due to the limited interaction between government bodies, private organizations, and NGOs along with poor community-level participation from the residents of Powai, one agency did not compliment the work of others, resulting in a challenging environment for the comprehensive management of the Powai lake.

\subsection{Comparative analysis between LULC for $\mathbf{2 0 0 0}$ and 2018}

Figure 6 provides the area-wise comparative analysis of the identified six LULC categories based on the percentage change between 2000 and 2018. The greatest change was observed for the barren land (decrease by 98\%) followed by WH cover in the Powai lake (decrease by 57\%). The barren land inside the campus provided a potential
Fig. 5 Temporal analysis of Powai lake and water hyacinth cover between 2000 and 2018
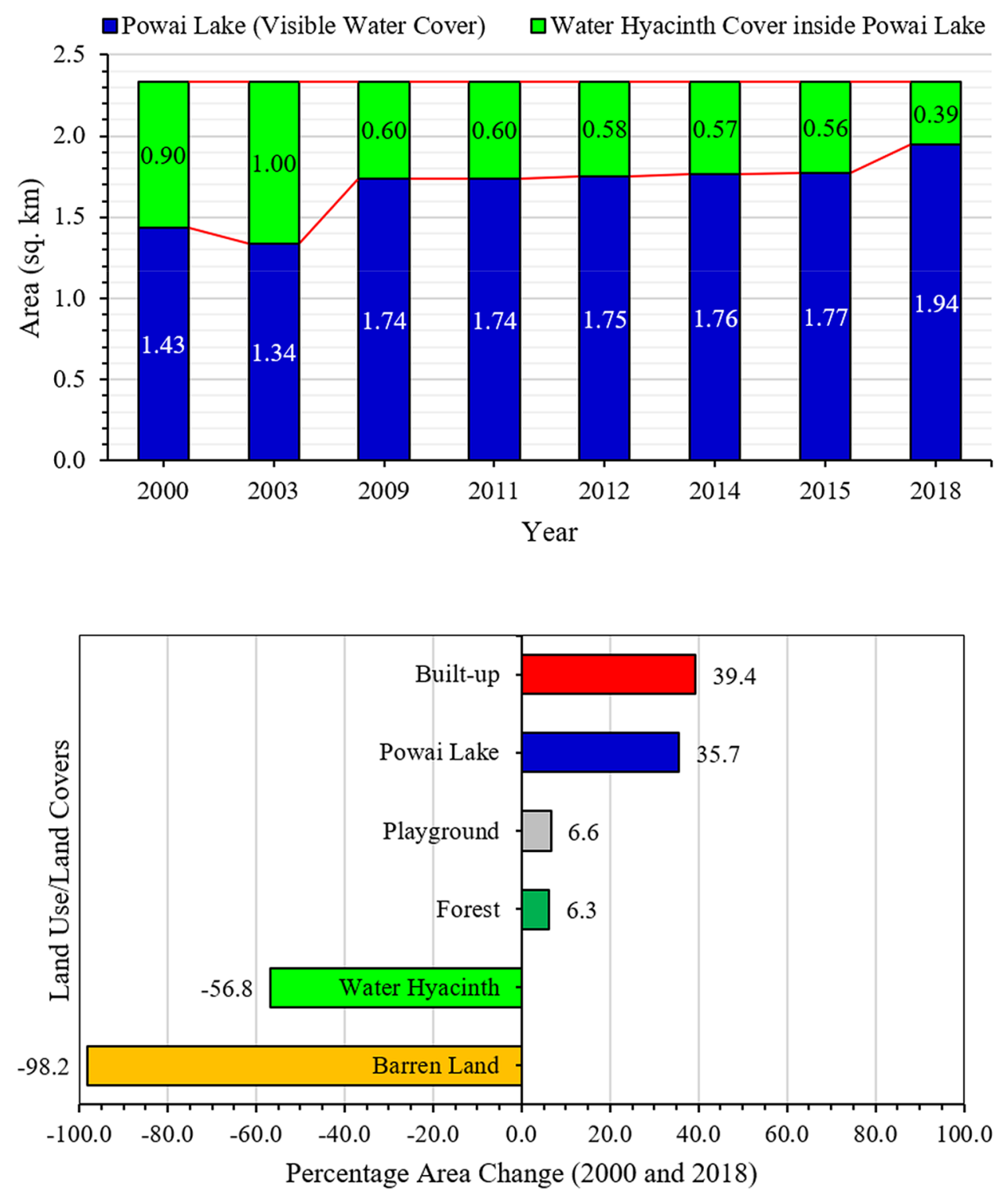

SN Applied Sciences
Fig. 6 Percentage change in the area of LULC classification of Indian Institute of Technology Bombay campus between 2000 and 2018 
scope for the physical development of the educational infrastructure. This was evident from the fact that the area under built-up increased by $\sim 40 \%\left(1.22 \mathrm{~km}^{2}\right.$ in 2018). On the other hand, the least change was recorded for forest cover that occupied $1.5 \mathrm{~km}^{2}$ (highest) in 2018 (increase by $\sim 6 \%$ ) followed by the area under the playground covering $0.1 \mathrm{~km}^{2}$ (increase by 7\%). The overall concern inferred from the aforementioned analysis was the drastic decline in the barren land (less than $1 \%$ available or $0.01 \mathrm{~km}^{2}$ in 2018). As in the future, there would be limited scopes for infrastructural development activities due to reduced land availability. Further construction may attract clearing forested land cover that might influence ecological balance inside the campus, whereas, in the case of Powai lake, the water cover improved considerably $(\sim 36 \%)$ due to which, the percentage area of lake cover, visible under satellite imagery, was recorded $83 \%$ against the $17 \%$ of the $\mathrm{WH}$ cover in 2018.

\subsection{Runoff versus built-up change}

To understand the rainfall-runoff behavior of the entire campus, the value of $W C N$ was calculated and compared with the built-up cover of the IITB campus. The depth of the runoff (in $\mathrm{mm}$ ) was used in the estimation of the WCN based on the magnitude of the rainfall (in $\mathrm{mm}$ ) received each year. The value of $W C N$ was observed fluctuating in the range of 36 to 40 (averaging 39) with an overall decreasing trend across the study period (Fig. 7). Comparing the years 2000 and 2018, there was a decrease in the WCN of about $8 \%$, although the built-up cover was observed correspondingly increasing since 2000 (Fig. 8). However, the relation of built-up cover with WCN was not proportional as identified in the case of the rainfall-runoff analysis. The decrease in the overall WCN was attributed to the corresponding increase in the forest cover within the campus from 2000 to 2018. Despite the increase in the built-up cover, the runoff remained comparatively unaffected, which indicated the sustainable design of the campus in controlling rainwater flow and its management. Furthermore, with the increase in the built-up area, there was a corresponding decrease observed in the rainfall and runoff volume; however, fluctuations were recorded during 2011 and 2014 when a sudden rise was observed (Fig. 8). The maximum rainfall and runoff volume was observed in the year 2011, while 2012 recorded the least.

\section{Discussions}

\subsection{Status and plans of infrastructure development post-2018}

The rapid expansion in student numbers resulted in an increase in infrastructure activities within the campus. The population of students increased from about 5500 in 2008 to nearly 11,000 in 2020 (Fig. 9), while that of the faculty increased from 300 in 2007 to 681 in 2020. The total population, including staff and from family quarters, was recorded as more than 20,000 in 2020 [21, 23-27]. This increased population within the campus was stressing the accommodating capacity of the institute.

To accommodate all the students and staff, additional buildings were needed. The institute planned to construct new hostels by targeting to bring more than 2,000 additional rooms for non-married students and 400 rooms for married students by the year 2022 [21-24]. In addition, existing old hostels were planned to be upgraded or reconstructed, depending on the state of the structures. For instance, hostel number 7 (established in 1963) was vacated in 2019 for reconstruction purposes, thus stressing the accommodation
Fig. 7 Average Runoff coefficient for the Indian Institute of Technology Bombay campus between 2000 and 2018

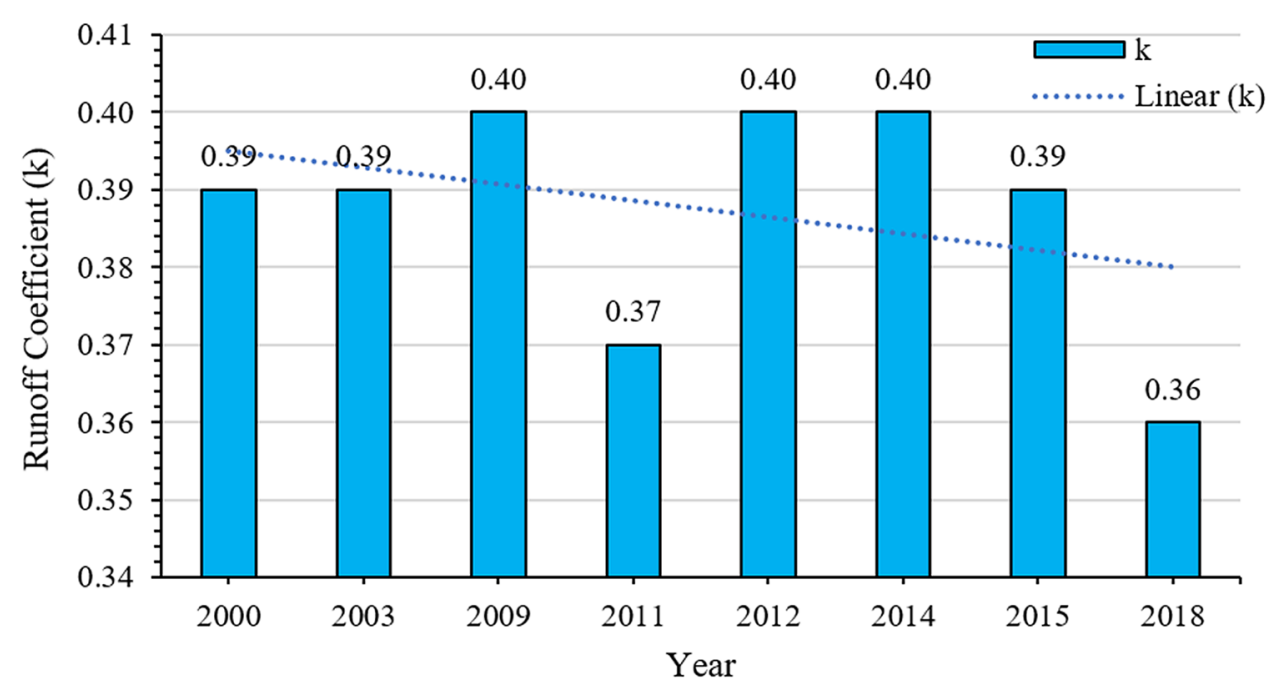


Fig. 8 Variation of runoff and rainfall volume against the built-up cover area between 2000 and 2018 at the campus of Indian Institute of Technology Bombay, India

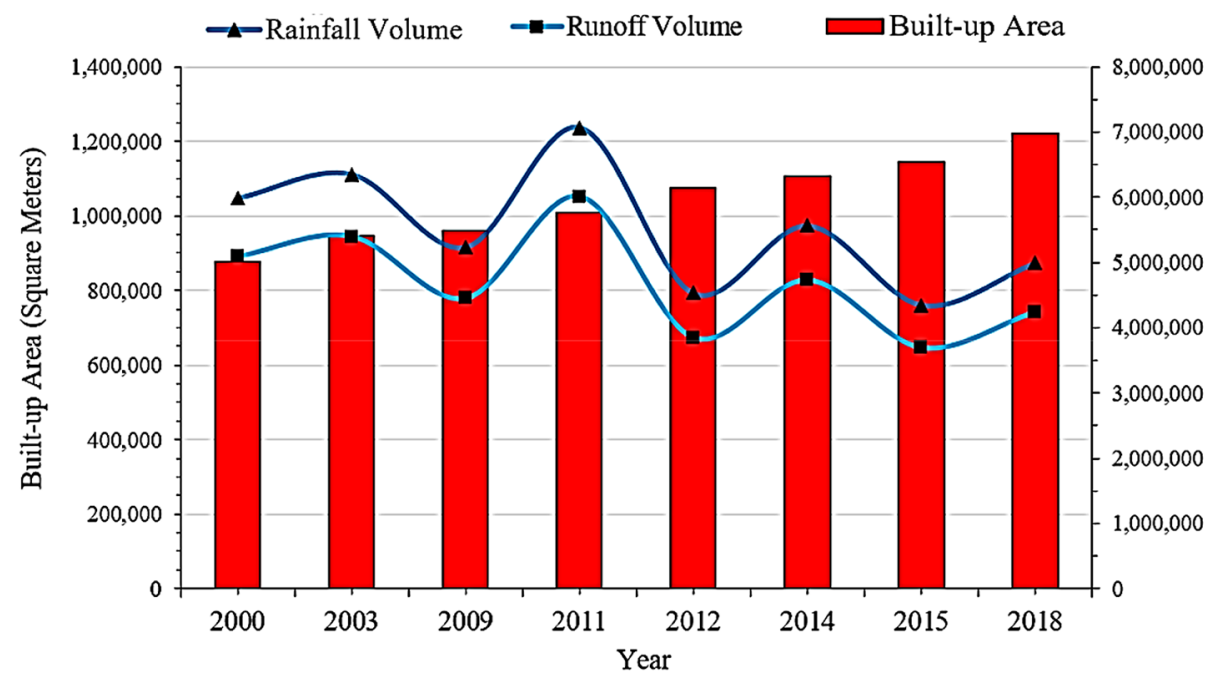

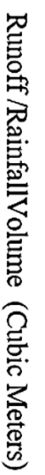

of the students further. Moreover, the construction for the hostel 18 (named hostel 1115 student capacity) of the institute was accomplished and made available for occupation by 2019, though the 19th hostel (named hostel number 17) was under the construction stage. Apart from hostels, the institute planned to establish 10 new multi-disciplinary centers, 10 additional cafeterias and food courts, and a multipurpose hall by 2022 [21-24]. A residential building having the capacity of 78 flats, a common building for three academic centers, a vertical extension of one academic building, and an expansion of the school building were a few of the other projects that commenced in 2018 [21-24]. The challenging facets behind this infrastructural development, according to the findings of this study, was the lack of barren land availability to accommodate all the targets. Based on the results, field investigations, and stakeholder's perception (Achary and Yughabala, personal communication, March 9, 2020), SWOT (strength - weakness - opportunity
- threat) analysis was conducted to better identify the focused problems (Table 1).

\subsection{Key observations from field investigation}

Given the context of minimizing flash flood events together with enhancing green cover amidst rapid infrastructural development, field investigation and qualitative surveys were conducted inside the IITB campus. Findings from the investigation revealed that the construction of any building was preceded by surveying the total vegetation and tree losses that could occur after the construction. Such losses of greenery were more or less compensated by additional plantation of the trees either in the vicinity of the constructed building or in the nearby gardens (Fig. 10b, e, f). However, this remained inconsistent and challenging, as a result of which, high fluctuations were recorded in the forest cover between 2000 and 2018. Nevertheless, the overall ecological balance so achieved resulted in better water budgeting among all hydrological
Fig. 9 Student-faculty population between 2010 and 2020 at the Indian Institute of Technology Bombay, India [21, 23-27]

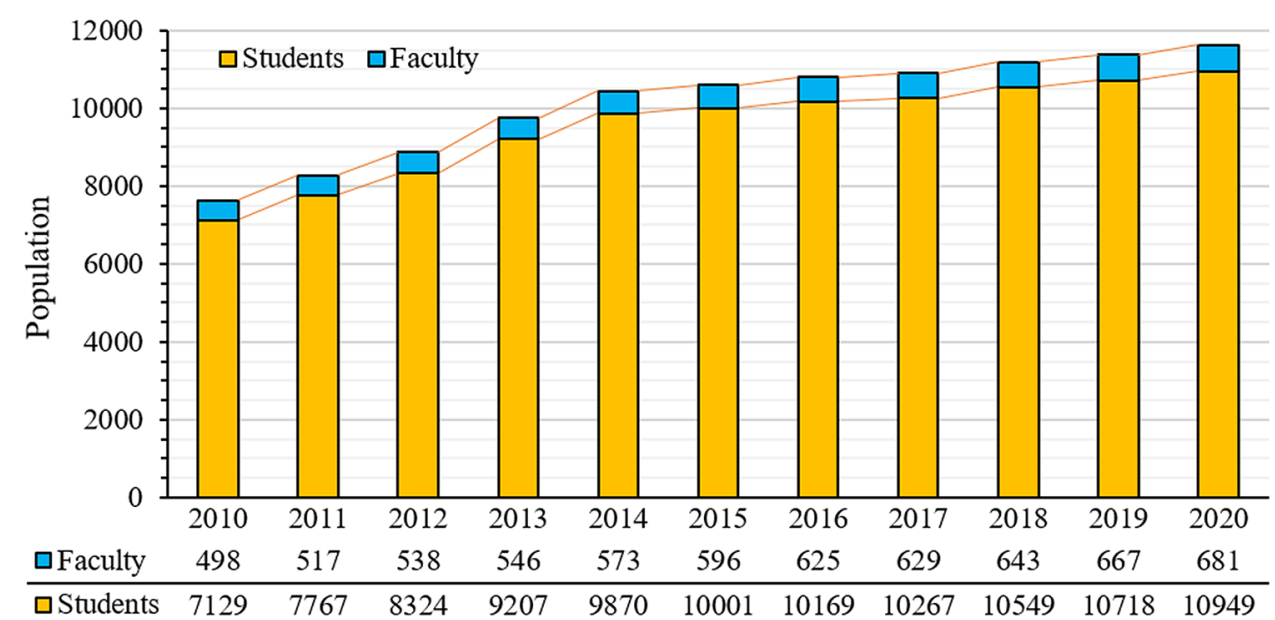


Table 1 SWOT analysis of the LULC of the campus of Indian Institute of Technology Bombay, India

\begin{tabular}{|c|c|}
\hline Strength & Weakness \\
\hline $\begin{array}{l}\text { Forest cover as the most dominated land cover ( } 52 \% \text { in } 2018) \text { within } \\
\text { campus boundary; influenced biodiversity and controlled flash flood } \\
\text { events }\end{array}$ & $\begin{array}{l}\text { Cutting of vegetation from the unurbanized region post-monsoon } \\
\text { negatively impacts ecosystem in large; events of flood, though } \\
\text { declined, continued to occur in low-lying regions }\end{array}$ \\
\hline $\begin{array}{l}\text { Despite rapid infrastructural development ( } 43 \% \text { built-up cover in } \\
\text { 2018), runoff remained comparatively less influenced }\end{array}$ & $\begin{array}{l}\text { Aging buildings requiring up-gradation; Limited hostels/residen- } \\
\text { tial buildings for accommodating rising population within the } \\
\text { campus }\end{array}$ \\
\hline $\begin{array}{l}\text { Declining water hyacinth cover in Powai lake aided biodiversity and } \\
\text { tourism }\end{array}$ & $\begin{array}{l}\text { Water hyacinth though declined but couldn't be eradicated, as a } \\
\text { result of which, its invasion more or less continued in Powai lake }\end{array}$ \\
\hline Opportunity & Threat \\
\hline $\begin{array}{l}\text { Plantation of the compensatory trees/saplings by provisioning } \\
\text { unpaved region in the vicinity of both existing and upcoming build- } \\
\text { ings }\end{array}$ & $\begin{array}{l}\text { Rapid infrastructural development coupled with additional building } \\
\text { constructions in the future may require to clear forested land cover }\end{array}$ \\
\hline $\begin{array}{l}\text { Provisioning plantation over the roof-top of the buildings so as to } \\
\text { create additional areas of green cover coupled with rainwater } \\
\text { harvesting schemes }\end{array}$ & $\begin{array}{l}\text { Limited land availability for compensatory plantation of the saplings } \\
\text { against the tress cut/cleared during the past or for the upcoming } \\
\text { construction projects may deteriorate green cover }\end{array}$ \\
\hline $\begin{array}{l}\text { Awareness campaigns by bringing diverse stakeholders of campus } \\
\text { together to learn and implement best management practices }\end{array}$ & $\begin{array}{l}\text { Further increment in the built-up cover may increase surface runoff } \\
\text { against natural infiltration and may deplete groundwater levels }\end{array}$ \\
\hline
\end{tabular}

processes like runoff and infiltration stability. This was considered one of the attributes of the stable weighted curve number estimated since 2012. Besides this, the roads were the major contributor to the built-up cover preventing the infiltration of the rainfall, apart from the infrastructural cover. But the closely planted trees along the major and minor roads at all locations receive the surface flow from the roads and thus regulate the process of the infiltration to a considerable extent (Fig. 10a). The slopes along the sides of the road were observed as a guider diverting rainwater to the stormwater canal (Fig. 10c). In general, all the aforementioned measures and collective efforts from the IITB transformed the campus into a testbed for pilot projects, for instance growing sapling in challengeable/ inaccessible areas, such as in built-up or parking areas (Fig. 10d), at the periphery of Powai lake, and remote baren land areas. These strategically located gardens/plantations were instrumental in acting as bio-retention ponds.

\subsection{Status and recommendations for sustainable campus development}

The fact claimed by the website of IITB - "...the campus' green cover has been maintained and even increased over the years" [25-27] about the increase in the green cover appeared justifying with the present GIS-based study work conducted between 2000 and 2018. Analysis of the results indicated that the infrastructural development in the IITB campus happened by the conversion of the unused region of the campus into a built-up cover; however, it could not be accredited to deforestation. Another attribute to this hypothesis was the recurrent celebration of world environment day and associated events like forestation and plantation drives conducted inside the campus, which kept the ecological balance alive. The team under the National Service Scheme (NSS) of IITB (a student-run organization) continued organizing modernization programs aiming to maintain and enhance the richness of the biodiversity (flora and fauna) inside and outside of the campus [30,31]. Their events on biodiversity mapping, sampling collection drive, nature walk, and sampling transplant, sustained awareness within and outside the society of IITB. A student-run social body called 'Abhyuday' (Sanskrit word, meaning 'sunrise') continued organizing pioneering events on Powai lake cleanup to promote a cleaner, greener, and healthier environment in association with local NGOs and BMC [29]. Another student-run sociotechnical body, the 'Sustainability Cell' of IITB was actively involved in the enviro-socio-economic development of the campus [28].

Besides student-run bodies, institute-level committees were formed to address the prevailing issues focusing on the implications of the rainfall-runoff behavior, and impacts of the rapid built-up growth on campus ecology. This included the Green Campus Initiative (GCl) committee established in 2010 [20] and the Institute Strategy and Planning Committee (ISPC) active since 2015 [20, 21]. They collectively emphasized cleaner and greener campus strategies coupled with designing campus policies to promote sustainable practices and maintain the flora and fauna. All the aforementioned organizations primarily involved experts, professors, and students in planning, thereby creating a positive platform in the institute for discussions, debates, and implementation of innovative 
Fig. 10 Sustainable initiatives taken for plantation across diverse LULC inside the campus of Indian Institute of Technology Bombay, India ( Source: Field investigation)

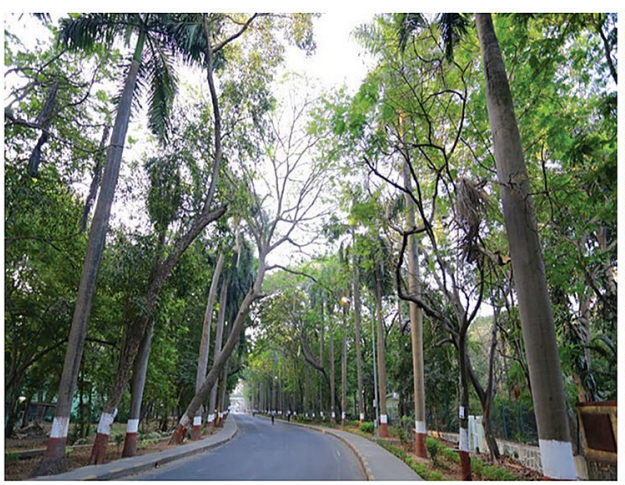

(a). Roadside plantation

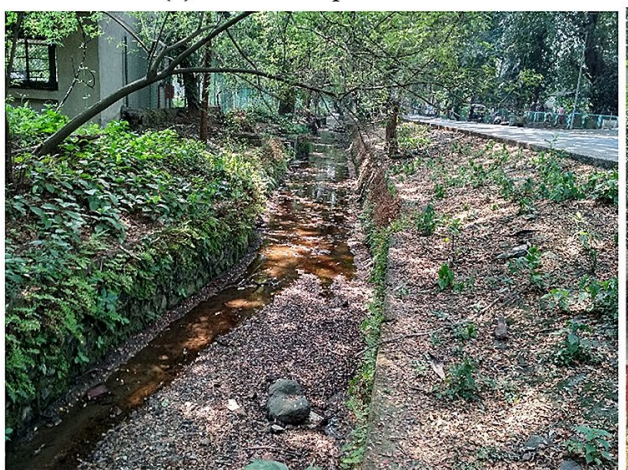

(c) Roadside slope to divert rainwater

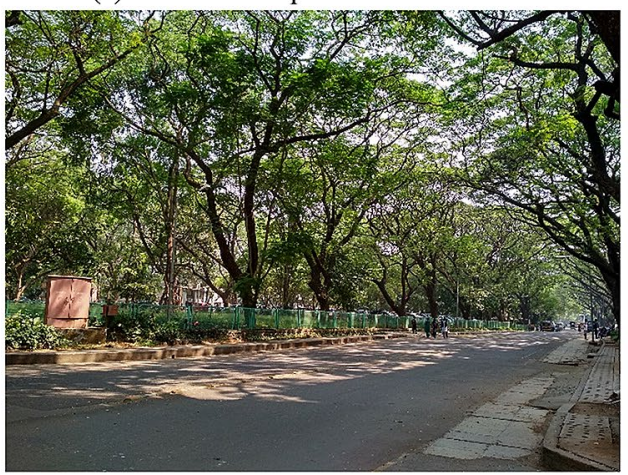

(e) Campus nursey zone

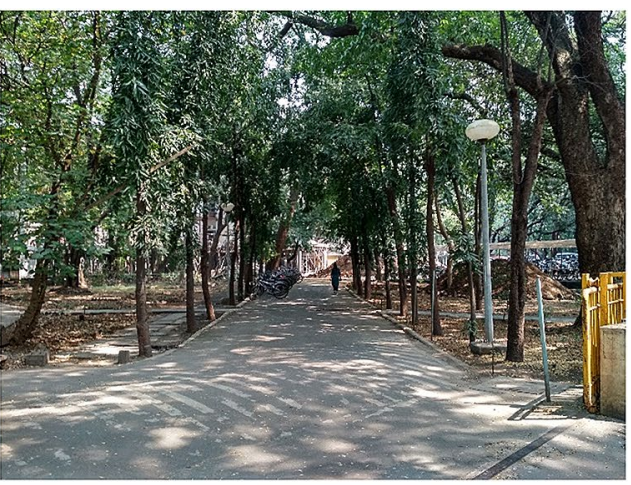

(b). Compensatory plantation

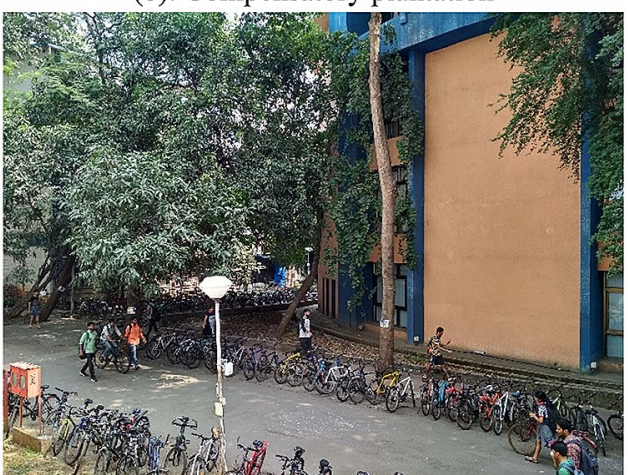

(d) Plantation in the parking/built-up zone

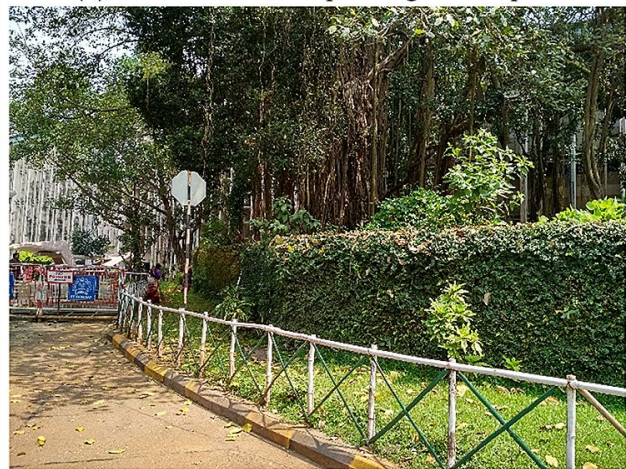

(f) Plantation in the garden of the main building ideas on sustainable campus development. In this regard, evidence on the conception of sustainable practices in the designs and the planning of the campus was identified and site-specific recommendations were articulated (Table 2).

\subsection{Learnings from past studies}

There are yet studies that focused on spatio-temporal variation of landscape patterns, wherein they considered complex interactions of social, economic, demographic, technological, political, biophysical, and cultural factors, for example Behera et al. [5], Hounkpè et al. [19], and Munthali et al. [46]. Swotting the key findings from such studies and assessing their relevance for managing academic institutions can oblige as an imperative benchmark for academicians, policymakers, institutional planners, and natural resource managers. Shimrah et al. [61] used FRAGSTATS (a simulation model) to monitor the vegetation status of Shirui hill, located in Manipur state, India, in which socio-economic data collection was made by conducting Participatory Rural Appraisal (PRA). Conducting activities parallel to PRA in an academic campus on a semester basis can aid in cataloging focused issues concerning rainfallrunoff behavior, green health, and overall hydro-ecological stability, given infrastructural development. At the same time, conducting a modeling-based investigation to predict future landscape transformation can further inform the academic authorities to develop holistic campus-scale sustainable development initiatives. Singh et al. [62], in their studies on the modeling of LULC change of Tons River Basin, Madhya Pradesh, India, demonstrated that 


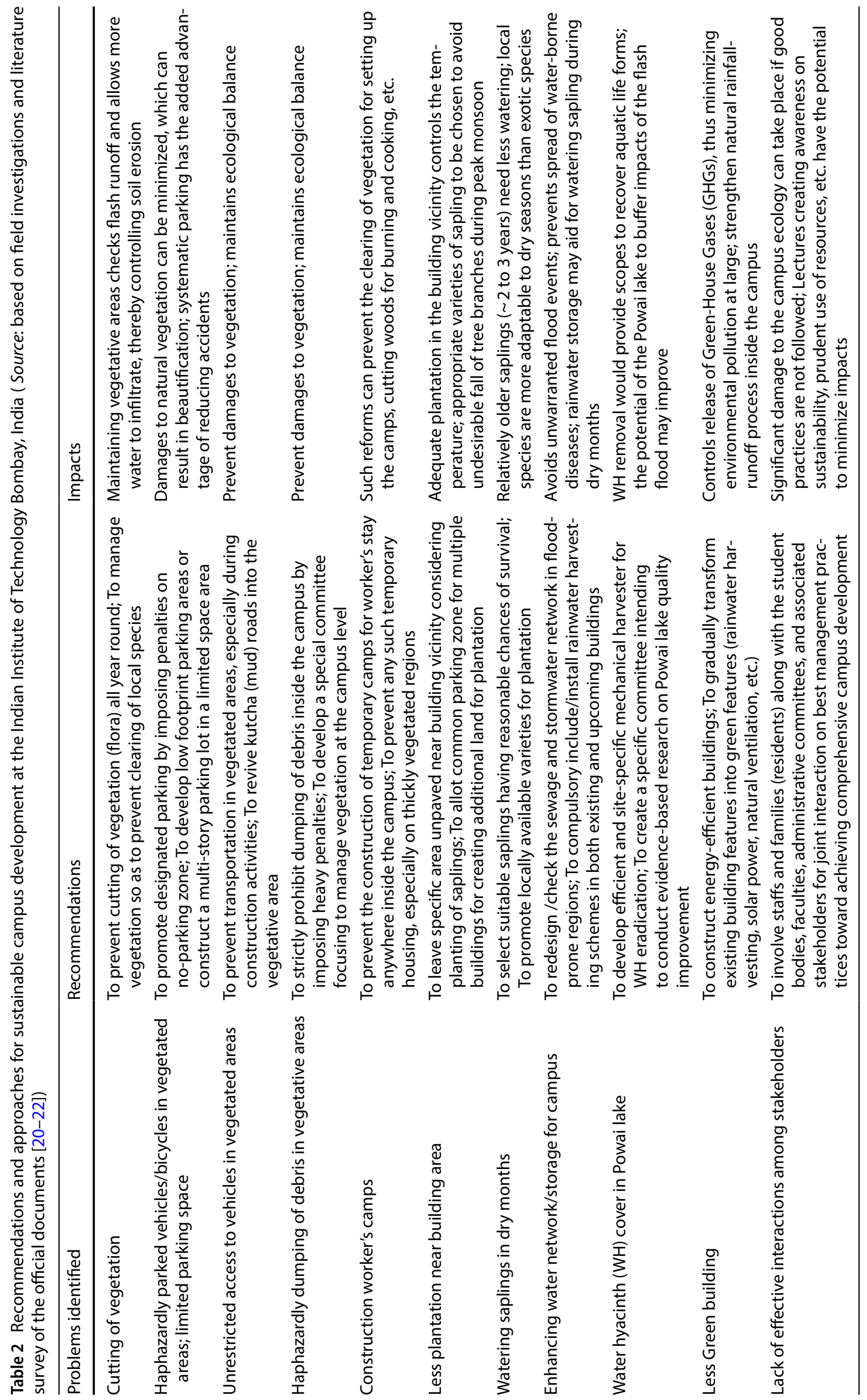


the simulated future-LULC maps may provide strategic guidelines to land-use planning and approaches to reduce deforestation that can serve as an early warning system of the future effects of LULC. Advanced techniques in RS and GIS, such as Cellular Automata Markov Chain Model (CAMCM), are readily used to identify the spatial and temporal changes that have occurred in LULC in the past, current, leading to prediction of future contexts $[4,62]$.

\subsection{Future scopes}

The developing campuses are more vulnerable to rapid LULC changes, in case, not enough consideration is given in devising sustainable strategies for overall holistic campus development. Based on the results and discussions, this study proposes to focus on the following attributes in future investigations for the IITB campus:

- In order to develop a green model, holistic approaches are further needed to improving sectors like solid waste management (to eradicate landfills), wastewater management (to reduce water hyacinth cover in Powai lake; invading as a result of the discharge of the wastewater), smarter and greener buildings (to install rainwater harvesting coupled with roof-top plantation making maximum utilization of rainfall and minimizing runoff), etc. Similar initiatives with characteristics like lower carbon footprint [57] and water footprint, lower emission, and zero discharge could further aid in controlling the pollution level, leading to an overall stability in terms of biodiversity and rainfall-runoff regime.

- There is a need to develop and implement cleaner and green technologies on a pilot basis to evaluate their viability in the campus context. Though the rising population inside campus compelled further constructions of buildings, the convergence of conventional construction techniques with green building concepts could be a more sustainable approach. Moreover, alternatives to conserving green cover amidst new construction needed to be explored, given declining barren land (mostly utilized for construction) and accommodating further constructions (goals) without deforestation.

- Monitoring, implementing, and enabling the aforementioned scopes may further need a sensor-based network inside the campus to gauge its sustainability metrics. Under such a context, the necessity for conducting LULC studies to locate sufficient green spaces, given new constructions, becomes paramount. Therefore, the result of LULC changes and its further analysis made in this study could provide a potential foundation to the planners for conducting advanced studies in the direction of developing a green campus.
- Since the land-use classes are generated by the manual classification method, the accuracy associated with the satellite imagery cannot be assessed using the Kappa coefficient and user's and producer's accuracies of individual classes. Future research should consider applying supervised classification for image processing and interpretation that can better differentiate between vegetation cover, barren land, and the forest (cover) leaves. A maximum-likelihood algorithm could be employed to detect the land-use classifications. The primary three geoprocessing tools, viz., create accuracy assessment points, update accuracy assessment points, and compute confusion matrix, can be employed to generate an accuracy assessment report.

- Determining vegetation-based indices, such as Normalized Difference Vegetation Index (NDVI), can provide baseline information on the health of the forest/vegetation (green cover) in particular and the environment in general. Additionally, the future results on the health of the vegetation can help to locate anthropogenic stressors. Such attempts might direct the revision of the existing policies concerning (1) careful water distribution in gardens, nursery zones, and areas of the old and compensatory plantation, and (2) future directions on infrastructural development prospects in a view of conserving green cover.

- Generating simulated scenarios to predict future behaviors of the rainfall-runoff process within changing trends of LULC using advance hydrological models could be yet another scope of a future study. Since the methods are simple, yet powerful, land managers can use these techniques effectively and periodically managing land and water resources, with minimal inputs.

\section{Summary and conclusions}

The present study, for the first time, examined the changes in the land-use land cover (LULC) pattern of the Indian Institute of Technology Bombay (IITB) campus from the period of 2000 to 2018 using remote sensing data and Geographical Information System. Parameters, such as greenery (vegetation and forest), water hyacinth (WH) cover in Powai lake, and other land uses and their impacts over the rainfall-runoff process, were studied and analyzed. The analysis was based on the simplified mass balance algorithms that can be used by land managers with less training efforts. Results indicated that the LULC change was major in the case of built-up, barren land, Powai lake, and the WH cover, while the LULC change observed was minor in the case of the forest cover and playground. The infrastructural development (built-up), including academic building, hostels, and roads, drastically increased in the 
study period, and the expansion of the built-up cover, in terms of the area, mostly happened through available barren land without interfering with the forest cover. The overall WH cover decreased significantly from $0.9 \mathrm{~km}^{2}$ in 2000 to $0.4 \mathrm{~km}^{2}$ in 2018 in the Powai lake, due to the aesthetics aspect of Hiranandani settlements, but the WH on the IITB's side was not much improved since 2000. Hiranandani was a tourist place, and thus, to maintain its tourism, the Powai lake at this zone was substantially maintained, which gradually reduced the WH cover to null in the year 2018 , thereby bringing back the lake to its initial coverage. The number of trees on the campus of IITB recorded a fluctuating increase, thus improving the green cover on the campus. As a result, a fluctuating slighter decrease in runoff volume to Powai lake was observed despite the rapid rise in the built-up area. This happened because of the increase in the number of trees in the gardens of all buildings and along both sides of the major and minor roads including the surrounding area of the Powai lake. The various student-run social and technical bodies along with administrative and institute committees of IITB have taken appropriate measures to maintain the green cover within the campus, which resulted in keeping the check over high runoff discharge.

This paper further summarized how the infrastructural development in IITB has changed the LULC pattern and documented the potential impacts of the same on the green cover, runoff patterns and hydrological balance inside the campus. Lessons learned from substantial LULC change assessments can lead to sustainable design for eco-friendly LULC which could be an alternative for any campus. Based on the major findings from the present study, the following conclusions were drawn:

- The IITB campus and its surrounding region witnessed more rainfall than the average annual rainfall of Mumbai. It was observed during field observation and remote sensing studies that the forest (green) cover was the most dominating land use inside campus, coupled with the presence of the national park in the campus vicinity. It can be concluded that the green cover caused higher rainfall in the region. Therefore, careful management strategies, through the lens of green campus initiatives, for controlling events of flash flood amidst new constructions become obligatory.

- Removal of the water hyacinth from Powai lake, though appeared challenging, was achievable given the fact that the Hiranandani complex was able to clear it to a considerable extent. Therefore, the maintenance aspects of the lake not only needed higher prioritization but also needed the participatory-based involvement of diverse stakeholders.
- Despite rapid construction activities, the events of flash floods (due to higher runoff) within the campus remained dormant. Apart from appropriate water routing and discharging surplus runoff into Powai lake, it was concluded that the forest cover, or more specifically the greater density of the trees, caused higher infiltration of the rain against surface runoff.

- The evidence that the weighted curve number unevenly declined across the study period against the increasing built-up cover concluded that the systematic campus design, with effective implementation of the green initiatives, can maintain hydro-ecological balance without compromising with the environmental services.

- The study finally concluded that the limited land availability for future constructions must be coupled with exploring appropriate strategies for sustainable and eco-friendly constructions, given the threat to the green cover. Green technologies, such as roof-top plantation and green building conceptions, could be employed for creating additional green spaces inside the campus.

Acknowledgements The administration and various active organizations inside IIT Bombay including Abhyuday, National Service Scheme, Sustainability Cell, Green Campus Initiative Committee, and Institute Strategy and Planning Committee are gratefully acknowledged. The authors sincerely acknowledge the Free and Open-Source Software for Education (FOSSEE), from IIT Bombay, for providing training on QGIS. The authors extend gratitude to Ms. Yughabala and Mr. Dineshan Achary (staff at the Center for Technology Alternatives for Rural Areas-CTARA) for providing valuable insights and recommendations.

Funding The authors acknowledge the funding from the Ministry of Human Resources Development (MHRD), Government of India.

\section{Compliance with ethical standards}

Conflict of interest The authors declare that the research was conducted in the absence of any commercial or financial and non-financial relationships that could be construed as a potential conflict of interest.

Open Access This article is licensed under a Creative Commons Attribution 4.0 International License, which permits use, sharing, adaptation, distribution and reproduction in any medium or format, as long as you give appropriate credit to the original author(s) and the source, provide a link to the Creative Commons licence, and indicate if changes were made. The images or other third party material in this article are included in the article's Creative Commons licence, unless indicated otherwise in a credit line to the material. If material is not included in the article's Creative Commons licence and your intended use is not permitted by statutory regulation or exceeds the permitted use, you will need to obtain permission directly from the copyright holder. To view a copy of this licence, visit http://creativecommons .org/licenses/by/4.0/. 


\section{References}

1. Afrin S, Gupta A, Farjad B, Ahmed MR, Achari G, Hassan QK (2019) Development of land-use/land-cover maps using Landsat-8 and MODIS Data, and their integration for hydro-ecological applications. Sensors 19(22):4891. https://doi.org/10.3390/s19224891

2. Agoramoorthy G, Chaudhary S, Chinnasamy P, Hsu MJ (2016) Harvesting river water through small dams promote positive environmental impact. Environ Monit Assess 188(11)

3. Ahmad F, Goparaju L, Qayum A (2017) LULC analysis of urban spaces using Markov chain predictive model at Ranchi in India. Spat Inf Res 25(3):351-359. https://doi.org/10.1007/s4132 4-017-0102-x

4. Behera MD, Borate SN, Panda SN, Behera PR, Roy PS (2012) Modelling and analyzing the watershed dynamics using Cellular Automata (CA)-Markov model-A geo-information based approach. J Earth Syst Sci 121(4):1011-1024. https://doi. org/10.1007/s12040-012-0207-5

5. Behera MD, Tripathi P, Das P, Srivastava SK, Roy PS, Joshi C, Behera PR, Deka J, Kumar P, Khan ML, Tripathi OP (2018) Remote sensing based deforestation analysis in Mahanadi and Brahmaputra river basin in India since 1985. J Environ Manage 206:1192-1203. https://doi.org/10.1016/j.jenvman.2017.10.015

6. Boughton WC (1989) A review of the USDA SCS curve number method. Soil Res 27(3):511-523. https://doi.org/10.1071/SR989 0511

7. Castilla G, Hay GG, Ruiz-Gallardo JR (2008) Size-constrained region merging (SCRM). Photogramm Eng Remote Sens 74(4):409-419. https://doi.org/10.14358/PERS.74.4.409

8. Chauhan JD (2020) Higher education in India-issues, challenges and suggestions. Higher Edu 5(1):33-36. https://rrjournals.com/ wp-content/uploads/2020/01/33-36_RRIJM200501010.pdf

9. Chaware S, Patil N, Satpute G, Apturkar S, Tingre A, Bante C, Deshkar B (2020) Google Earth imageries for validating groundwater recharge zone in basaltic region. J Geol Soc India 96(4):374-384. https://doi.org/10.1007/s12594-020-1566-1

10. Chinnasamy P, Hubbart JA (2015) Stream and shallow groundwater nutrient concentrations in an Ozark forested riparian zone of the central USA. Environ Earth Sci 73(10):6577-6590

11. Chinnasamy P, Parikh A (2020) Remote sensing-based assessment of coastal regulation zones in India: a case study of Mumbai. Environ Dev Sustain. https://doi.org/10.1007/s1066 8-020-00955-z

12. Chinnasamy $P$, Misra G, Shah T, Maheshwari B, Prathapar $S$ (2015) Evaluating the effectiveness of water infrastructures for increasing groundwater recharge and agricultural production - A case study of Gujarat, India. Agric Water Manag 158:179-188

13. Chinnasamy P, Honap VP, Maske AB (2020) Impact of 2018 Kerala floods on soil erosion: need for post-disaster soil management. J Indian Soc Remote Sens 48(10):1373-1388

14. Dash RK, Sahoo P (2010) Economic growth in India: the role of physical and social infrastructure. J Econ Policy Reform 13(4):373-385. https://doi.org/10.1080/17487870.2010.52398 0

15. Dunbar MJ, Acreman MC (2001) Applied hydro-ecological science for the twenty-first century. In: Acreman MC (ed) Hydro-ecology: linking hydrology and aquatic ecology (Proc. Birmingham, UK, Workshop, July 1999). IAHS, Wallingford, pp $1-18$

16. GebreMedhin A, Biruh W, Govindu V, Demissie B, Mehari A (2019) Detection of urban land use land cover dynamics using GIS and remote sensing: a case study of Axum town, Northern Ethiopia. J Indian Soc Remote Sens 47(7):1209-1222. https:// doi.org/10.1007/s12524-019-00974-y
17. Goldblatt R, You W, Hanson G, Khandelwal AK (2016) Detecting the boundaries of urban areas in India: a dataset for pixelbased image classification in Google Earth Engine. Remote Sens 8(8):634. https://doi.org/10.3390/rs8080634

18. Hjelmfelt AT Jr (1991) Investigation of curve number procedure. J Hydraul Eng 117(6):725-737. https://doi.org/10.1061/ (ASCE)0733-9429(1991)117:6(725)

19. Hounkpè J, Diekkrüger B, Afouda AA, Sintondji LO (2019) Land use change increases flood hazard: a multi-modelling approach to assess change in flood characteristics driven by socio-economic land use change scenarios. Nat Hazards 98(3):1021-1050. https://doi.org/10.1007/s11069-018-3557-8

20. Indian Institute of Technology Bombay (2010). Report of the green campus initiative (GCI) committee. IIT Bombay Publishing. https://www.iitsystem.ac.in/sites/default/files/greenagend a/2/6ccc612a157c22b1e13c26b.pdf. Accessed 11 October 2020

21. Indian Institute of Technology Bombay (2016) Information on the strategic plan (2017-2022). IIT Bombay Publishing. https ://www.iitb.ac.in/en/about-iit-bombay/iit-bombay-strategicplan-2017-22. Accessed 11 Oct 2020

22. Indian Institute of Technology Bombay (2016) IIT Bombay strategic plan (2017-2022): supplementary document. IIT Bombay Publishing. http://www.iitb.ac.in/sites/default/files/Supplement ary\%20Document.pdf . Accessed 11 October 2020

23. Indian Institute of Technology Bombay (2017) Statistics for the year 2017-2018. IIT Bombay Publishing. http://www.iitb.ac.in/ sites/default/files/PocketStatistics\%202017-18.pdf. Accessed 11 October 2020

24. Indian Institute of Technology Bombay (2018) Statistics for the year 2018-2019. IIT Bombay Publishing. http://www.iitb.ac.in/ sites/default/files/Statistics\%20for\%20the\%20\%20year\%20201 8-19.pdf. Accessed 11 October 2020

25. Indian Institute of Technology Bombay (2018) Annual report 2018-2019. IIT Bombay Publishing. http://www.iitb.ac.in/sites /default/files/AnnualReport/2019/AR_IIT\%20BOMBAY\%20201 9.pdf. Accessed 11 October 2020

26. Indian Institute of Technology Bombay (2020) About IIT Bombay (official website). http://www.iitb.ac.in/en/about-iit-bomba y. Accessed 11 October 2020

27. Indian Institute of Technology Bombay (2020) IIT Bombay director's report. IIT Bombay Publishing. http://www.iitb.ac.in/sites /default/files/IIT\%20Bombay_Directors\%20Report\%20202 0_Final.pdf. Accessed 11 October 2020

28. Indian Institute of Technology Bombay (2020) Sustainability cell-a student run social body (official website). https://www. insti.app/org/sustainability-cell. Accessed 11 October 2020

29. Indian Institute of Technology Bombay (2020) Abhuyday-a social body of IIT Bombay (official website). http://abhyudayii tb.org/campaigns.html. Accessed 11 October 2020

30. Indian Institute of Technology Bombay (2020) Green campus. National Service Scheme Publishing (official website). https:// gymkhana.iitb.ac.in/ nss/depts/?dept=GC. Accessed 11 October 2020

31. Indian Institute of Technology Bombay (2020) Bird of IIT Bombay. National Service Scheme Publishing (official website). https ://gymkhana.iitb.ac.in/ nss/birds/home/. Accessed 11 October 2020

32. Izaga F, Schutzer JG, Kantamaneni K (2019) Perspectives on green: recent urbanisation works and measures in Brazil and India. In: Mell I, Lemes de Oliveira F (eds) Planning cities with nature. Springer, Cham, pp 199-214

33. Kaliraj S, Chandrasekar N, Ramachandran KK, Srinivas Y, Saravanan S (2017) Coastal landuse and land cover change and transformations of Kanyakumari coast, India using remote sensing and GIS. Egyptian J Remote Sens Space Sci 20(2):169-185. https://doi.org/10.1016/j.ejrs.2017.04.003 
34. Kaimaris D, Georgoula O, Patias P, Stylianidis E (2011) Comparative analysis on the archaeological content of imagery from Google Earth. J Cultural Heritage 12(3):263-269. https://doi. org/10.1016/j.culher.2010.12.007

35. Kampouraki M, Wood GA, Brewer TR (2008) Opportunities and limitations of object based image analysis for detecting urban impervious and vegetated surfaces using true-colour aerial photography. In: Blaschke T, Lang S, Hay GJ (eds) Object-based image analysis, Lecture Notes in Geoinformation and Cartography, Springer, Berlin, Heidelberg

36. Khan R, Jhariya DC (2018) Assessment of land-use and landcover change and its impact on groundwater quality using remote sensing and GIS techniques in Raipur City, Chhattisgarh, India. J Geol Soc India 92(1):59-66. https://doi.org/10.1007/ s12594-018-0953-3

37. Kostianoy AG, Soloviev DM, Pešić V (2020) Application of Google Earth in mapping intermittent rivers of Montenegro. In: Pešić $V$, Paunović M, Kostianoy A (eds) The rivers of Montenegro. The handbook of environmental chemistry, vol 93. Springer, Cham

38. Krishnaveni KS, Anilkumar PP (2020) Managing urban sprawl using remote sensing and GIS. Int Arch Photogramm Remote Sens Spat Inf Sci 42:59-66. https://doi.org/10.5194/isprs-archi ves-XLII-3-W11-59-2020

39. Liang J, Gong J, Li W (2018) Applications and impacts of Google Earth: a decadal review (2006-2016). ISPRS J Photogramm Remote Sens 146:91-107. https://doi.org/10.1016/j.isprs jprs.2018.08.019

40. Lillesand T, Kiefer RW, Chipman J (2015) Remote sensing and image interpretation. John Wiley and Sons.

41. Maliqi E, Singh SK (2019) Quantitative estimation of soil erosion using open-access earth observation data sets and erosion potential model. Water Conserv Sci Eng 4(4):187-200. https:// doi.org/10.1007/s41101-019-00078-1

42. Manchanda R (2008) Monastery, sanctuary, laboratory: 50 years of IIT-Bombay. Macmillan, New Delhi

43. Mishra SK, Singh VP (2013) Soil conservation service curve number (SCS-CN) methodology. Springer Science and Business Media.

44. Mukherjee $F(2020)$ Institutional networks of association for GIS use: the case of an urban local body in India. Ann Am Assoc Geogr 110(5):1445-1463. https://doi.org/10.1080/24694 452.2019.1691495

45. Mumbai Climate Report (2020) Rainfall in Mumbai, India. http://www.mumbai.climatemps.com/precipitation.php. Accessed 11 Oct 2020

46. Munthali MG, Mustak S, Adeola A, Botai J, Singh SK, Davis N (2020) Modelling land use and land cover dynamics of Dedza district of Malawi using hybrid Cellular Automata and Markov model. Remote Sens Appl Soc Environ 17:100276. https://doi. org/10.1016/j.rsase.2019.100276

47. Natarajan K, Latva-Käyrä P, Zyadin A, Pelkonen P (2016) New methodological approach for biomass resource assessment in India using GIS application and land use/land cover (LULC) maps. Renew Sustain Energy Rev 63:256-268. https://doi. org/10.1016/j.rser.2016.05.070

48. Natarajan S, Radhakrishnan N (2019) Simulation of extreme event-based rainfall-runoff process of an urban catchment area using HEC-HMS. Modeling Earth Syst Environ 5(4):18671881. https://doi.org/10.1007/s40808-019-00644-5

49. Pal S, Talukdar S (2020) Assessing the role of hydrological modifications on land use/land cover dynamics in Punarbhaba river basin of Indo-Bangladesh. Environ Dev Sustain 22(1):363-382. https://doi.org/10.1007/s10668-018-0205-0

50. Ramaiah M, Avtar R (2019) Urban green spaces and their need in cities of rapidly urbanizing India: a review. Urban Sci 3(3):94. https://doi.org/10.3390/urbansci3030094
51. Ranger N, Hallegatte S, Bhattacharya S, Bachu M, Priya S, Dhore K, Rafique F, Mathur P, Naville N, Henriet F, Herweijer C (2011) An assessment of the potential impact of climate change on flood risk in Mumbai. Climatic Change 104(1):139-167. https:// doi.org/10.1007/s10584-010-9979-2

52. Rawat KS, Singh SK (2017) Estimation of surface runoff from semi-arid ungauged agricultural watershed using SCS-CN method and earth observation data sets. Water Conserv Sci Eng 1(4):233-247. https://doi.org/10.1007/s41101-017-0016-4

53. Rawat KS, Singh SK (2018) Appraisal of soil conservation capacity using NDVI model-based C factor of RUSLE model for a semi arid ungauged watershed: A case study. Water Conserv Sci Eng 3(1):47-58. https://doi.org/10.1007/s41101-018-0042-x

54. Rawat KS, Singh SK, Szilard S (2020) Comparative evaluation of models to estimate direct runoff volume from an agricultural watershed. Geol Ecol Landsc. https://doi.org/10.1080/24749 508.2020.1833629

55. Regional Meteorological Center (RMC) Mumbai. (2019). Mumbai rainfall data (official website). http://www.imdmumbai.gov.in/ scripts/detail.asp?r. Accessed 11 Oct 2020

56. Sahoo S, Dhar A, Debsarkar A, Kar A (2018) Impact of water demand on hydrological regime under climate and LULC change scenarios. Environ Earth Sci 77(9):341(1-19). https:// doi.org/https://doi.org/10.1007/s12665-018-7531-2

57. Salata F, Golasi I, Di Salvatore M, de Lieto VA (2016) Energy and reliability optimization of a system that combines daylighting and artificial sources. A case study carried out in academic buildings. Appl Energy 169:250-266. https://doi.org/10.1016/j.apene rgy.2016.02.022

58. Satya BA, Shashi M, Deva P (2020) Future land use land cover scenario simulation using open source GIS for the city of Warangal, Telangana, India. Appl Geomatics 25:281-290. https://doi. org/10.1007/s12518-020-00298-4

59. Seto KC, Golden JS, Alberti M, Turner BL (2017) Sustainability in an urbanizing planet. Proc Natl Acad Sci 114(34):8935-8938. https://doi.org/10.1073/pnas.1606037114

60. Sheikh YA (2017) Higher education in India: challenges and opportunities. J Educ Pract 8(1):39-42. https://files.eric.ed.gov/ fulltext/EJ1131773.pdf

61. Shimrah T, Sarma K, Varga OG, Szilard S, Singh SK (2019) Quantitative assessment of landscape transformation using earth observation datasets in Shirui Hill of Manipur, India. Remote Sens Appl Soc Environ 15:100237. https://doi.org/10.1016/j. rsase.2019.100237

62. Singh SK, Srivastava PK, Szabó S, Petropoulos GP, Gupta M, Islam T (2017) Landscape transform and spatial metrics for mapping spatiotemporal land cover dynamics using Earth Observation data-sets. Geocarto Int 32(2):113-127. https://doi. org/10.1080/10106049.2015.1130084

63. Somvanshi SS, Bhalla O, Kunwar P, Singh M, Singh P (2020) Monitoring spatial LULC changes and its growth prediction based on statistical models and earth observation datasets of Gautam Budh Nagar, Uttar Pradesh, India. Environ Dev Sustain 22(2):1073-1091. https://doi.org/10.1007/s10668-018-0234-8

64. Srinivasan V, Suresh Kumar D, Chinnasamy P, Sulagna S, Sakthivel D, Paramasivam P, Lele S (2014) Water management in the Noyyal River basin a situation analysis

65. Srivastava A, Chinnasamy P (2021) Water management using traditional tank cascade systems: a case study of semi-arid region of Southern India. SN Appl Sci 3(3)

66. Subramanya K (2013) Engineering hydrology. Tata McGraw-Hill Education, New Delhi

67. Swaminathan A, Narayanan M, Blossom J, Venkataramanan R, Saunik S, Kim R, Subramanian SV (2020) The state of school infrastructure in the assembly constituencies of rural India: analysis of 11 census indicators from pre-primary to higher 
education. Int J Environ Res Public Health 17(1):296. https:// doi.org/10.3390/ijerph17010296

68. Taylor BT, Fernando P, Bauman AE, Williamson A, Craig JC, Redman S (2011) Measuring the quality of public open space using Google Earth. Am J Prev Med 40(2):105-112. https://doi. org/10.1016/j.amepre.2010.10.024

69. Taylor JR, Lovell ST (2012) Mapping public and private spaces of urban agriculture in Chicago through the analysis of highresolution aerial images in Google Earth. Landsc Urban Plan 108(1):57-70. https://doi.org/10.1016/j.landurbpla n.2012.08.001

70. Vijay R, Dey J, Sakhre S, Kumar R (2020) Impact of urbanization on creeks of Mumbai, India: a geospatial assessment approach. J Coast Conserv 24(1):1-6. https://doi.org/10.1007/s11852-01900721-y

71. Whitmeyer SJ (2012) Google Earth and virtual visualizations in geoscience education and research. Geological Society of America, USA

72. Xu Z, Zhao G (2016) Impact of urbanization on rainfall-runoff processes: case study in the Liangshui River Basin in Beijing, China. Proc Int Assoc Hydrol Sci 373:7-12. https://doi. org/10.5194/piahs-373-7-2016
73. Yu L, Gong P (2012) Google Earth as a virtual globe tool for Earth science applications at the global scale: progress and perspectives. Int J Remote Sens 33(12):3966-3986. https://doi. org/10.1080/01431161.2011.636081

74. Zekeng JC, Sebego R, Mphinyane WN, Mpalo M, Nayak D, Fobane JL, Onana JM, Funwi FP, Mbolo MM (2019) Land use and land cover changes in Doume Communal Forest in eastern Cameroon: implications for conservation and sustainable management. Model Earth Syst Environ 5(4):1801-1814. https://doi. org/10.1007/s40808-019-00637-4

75. Zope PE, Eldho TI, Jothiprakash V (2016) Impacts of land useland cover change and urbanization on flooding: a case study of Oshiwara River Basin in Mumbai, India. CATENA 145:142-154. https://doi.org/10.1016/j.catena.2016.06.009

Publisher's Note Springer Nature remains neutral with regard to jurisdictional claims in published maps and institutional affiliations. 